\title{
水应協調型人工リーフの形状の提案
}

Proposal for a configuration of artificial reef as harmonized with fishery

高木伸雄 ${ }^{*}$ 中山哲嚴、加藤広之 ${ }^{*}$

Nobuo Tkaki, Akiyosi Nakayam, Hiroyukikatou

\begin{abstract}
In Japan, the improvement works of revetment and offshore breakwater have been promoted for coastal conservation. However, recently in the coastarea, there are occurring lots of problems such as increasing of oceaniction and draining of natural resources. To cope with such problems, it is inevitably required that the coastal structures are to be improved on a multi-purpose basis and on the other hand, the related facilities are to be improved in view of environment like fishery resources.

In order to meet such social requirements, this Paper introduces a recommendable cross-section of the multi-purpose artificial reef which is observed most promising as a new model facilty for coastal conservation as well as fishery function.
\end{abstract}

1.はじめに

わが国では、海岸の保全を図るために、護岸や離岸堤等の整備を進められている。

しかし、近年、海岸域においては、海洋性レクリエーション等の増加、水産資源の枯渴など多くの問題が発生 している。このため、海岸施設の多目的な整備を進めるとともに、一方では、水産資源などの環境を考慮した施 設整備が求められている。

このような社会的要求に対応するために、人エリーフについて、水産効果調査および水理機能調査を行い、海 岸の保全を目的とするだけではなく、水産機能を付加した、新たな施設として期待されている多目的な人工リー フの断面形状について提案行うものである。

\section{2. 人エリーフの水産効果調査}

すでに施工されている人エリーフについて、水産効果を確認するために既往文献調査、潜水調査と発注者・漁 業関係者へのアンケート調査を実施した。

1)既往資料の収集整理および分析

既往文献のより、潜堤（離岸堤や増殖場などを含む）と着生成物の関係を整理する。

(1)潜堤構造諸元と増殖水産生物

潜堤構造諸元と增殖水産生物の関係を表一 1 に示す。

表 -1 消波構造諸元と增殖水産生物の関係（平均値）

\begin{tabular}{|c|c|c|c|c|}
\hline 項目 求産生物 & ウ & アワビ & コン ブ & イセエビ \\
\hline 潮位差（ HWL-LWL ) & $0.59 \mathrm{~m}$ & $1.29 \mathrm{~m}$ & $0.68 \mathrm{~m}$ & $1.93 \mathrm{~m}$ \\
\hline 設置水深（LWL-h） & $4.08 \mathrm{~m}$ & $6.30 \mathrm{~m}$ & $4.64 \mathrm{~m}$ & $8.80 \mathrm{~m}$ \\
\hline 天端水深 (LWL-R) & $1.13 \mathrm{~m}$ & $1.46 \mathrm{~m}$ & $1.37 \mathrm{~m}$ & $6.36 \mathrm{~m}$ \\
\hline 天端幅 & $4.19 \mathrm{~m}$ & $7.45 \mathrm{~m}$ & $2.95 \mathrm{~m}$ & $8.83 \mathrm{~m}$ \\
\hline
\end{tabular}

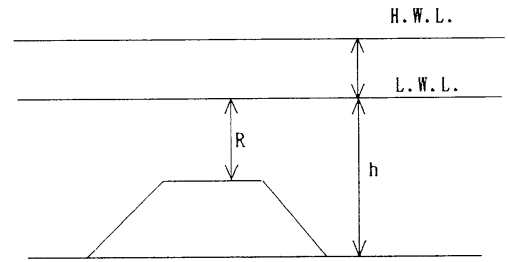

図 -1 潜堤諸元

表 - 1 より、対象とする生物により、天端幅や天端水深に大きな差がでていることがわかる。

* 正会員 財団法人漁港漁村建設技術研究所（港区赤坂6-13-16） 
(2)人エリーフに期待される水産生物

人エリーフは砂浜地帯では新たに岩礁域を造成することになり、磯根生物の増殖効果が期待される。さら に、岩盤地域においても、複雑な空隙と安定した岩礁を造成することになり、天然の漁場を拡大するポテン シャルを有すると考えられる。

したがって、水産協調型人エリーフに期待される水産生物は磯根生物全般にわたるが、特に、増殖効果を 期待すべき主な代表的水産生物は表一 2 となる。

\begin{tabular}{|c|c|}
\hline 軟体動物 & $\begin{array}{l}\text { サザエ、エゾアワビ、クロアワビ、マダカアワビ、メガイアワ } \\
\text { ビ、トコブシ、ハマグリ類、ウバガイ、アサリ類、クボガイ、 } \\
\text { バテイラ、コシダカガンガラ、キサゴ類、イガイ類、カキ類、 } \\
\text { ヤリイカ、アオリイカ、タコ類 }\end{array}$ \\
\hline 甲款類 & イセエビ \\
\hline 棘皮類 & $\begin{array}{l}\text { エゾバフンウニ、キタムラサキウニ、バフンウニ、アカウニ、 } \\
\text { ムラサキウニ、マナマコ }\end{array}$ \\
\hline 原索動物 & マボヤ \\
\hline 魚類 & $\begin{array}{l}\text { マダイ、クロダイ、ヒラメ、イシダイ、ソイ、メバル類、カサ } \\
\text { ゴ類、メジナ類、ハ夕類 }\end{array}$ \\
\hline 海草類 & $\begin{array}{l}\text { コンブ類、ワカメ類、テングサ類、オゴノリ類、イギス、モズ } \\
\text { ク類、ホンダワラ類 }\end{array}$ \\
\hline
\end{tabular}

なお、表一 2 における海草類は商品価値のあるものを示したが、砂浜の二枚貝をのぞく多くの魚介類は、 藻場を育成場としているので、藻場を形成する海草類（ホンダワラ類、アラメ、カジメ等）は水産効果の上 で、重要である。

また、水産協調型人エリーフに期待される水産生物は、表- 2 にとどまらず多岐にわたり、人工リ一フそ の屯のに固着する種や背後の静穩域で育成する種もあり、魚種のように、その生活史の一時期を人エリーフ で過ごすものもある。さらに、人エリーフを造成する海域により、対象種となる生物の生態は微妙に異なる。 以上のことから、水産効果を期待する対象種選定に当たっては、水産生物の生物環境調查を十分に行う必 要があろう。

(3)水産協調型人エリーフに必要とされる機能

表- 2 のような水産生物を増殖させるために、必要とされる機能は、築磯としての機能であり、既往文献 等の調查より、人エリーフ背後の静穏域での水産利用や砂浜海域の生物（二枚貝等）を別にすると、その機 能を集約すると以下の通りである。

人エリーフに望まれる機能

\section{・藻場としての機能}

・餌料としての寄り藻を滞留させる機能

・浮遊稚仔の着底を促進する機能

・複雑で多様な空間を形成する機能

2)生物調查

人エリーフの水産効果を確認するために、人エリーフが施工された地区の生物調査及びアンケート調查を実 施した。

(1)生物調查

a. 調查対象地区

山形県鶴岡市由良地区は山形県中央部に位置し、県内有数の海水浴場であり、景観を阻害しない消波構 造物として人エリーフが設置されている。

同地区の位置図を図-1に人エリーフの標準断面図を図 -2 に示す。

b. 対象地区選定理由

対象地区は以下の理由により、選定した。

・人エリーフ周辺には岩盤が無く、砂浜地帯における人エリーフの水産効果が把握できる。

・海象条件が厳しい条件での水産効果が確認できる。

b. 調查日時

1993 年 7 月 25 日、 1994 年 4 月 20 日 


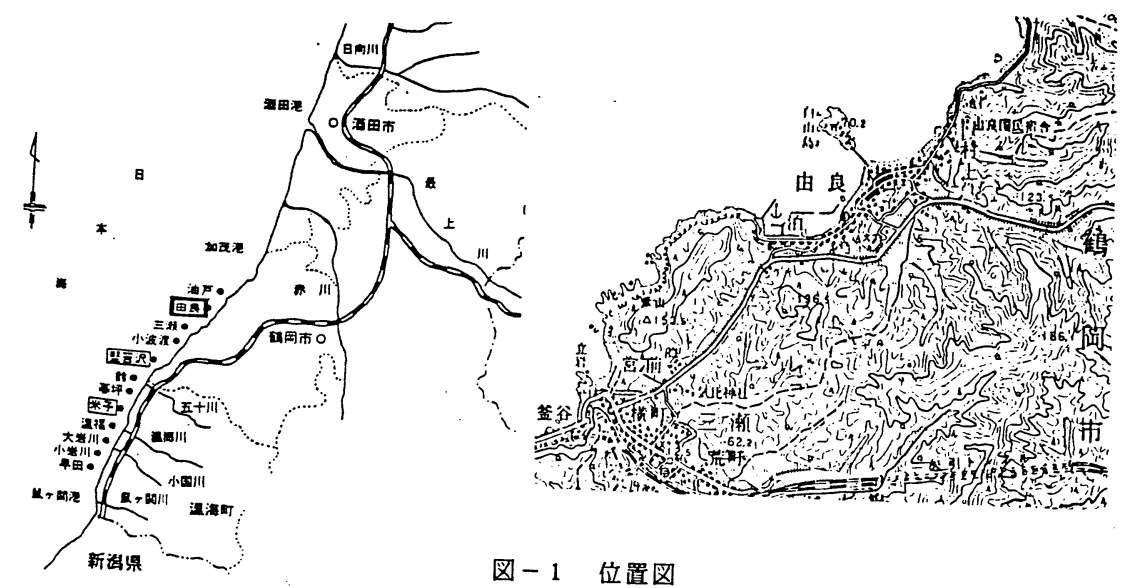

c. 調查方法

人エリーフ上に着生した海藻、貝類、人エリーフに蝟集する魚類の状況を目視観察および写真撮影を行 った。

また、目視観察では被覆ブロック上に貝類の着生が見られたため、ブロック天端面を100\%ととした場合 の着生生物種別の着生面積の割合（被度、単位\%）を測定した。

d. 調査結果

調查では植生の部分を岸沖方向（断面方向）に観察し、図－2 に示すように便宜的に沖側から、被覆 ブロックの名称を $\mathrm{A} \sim \mathrm{I}$ とした。

ブロックの被度調査結果を表一 $3.1 \sim 3.2$ に示す。

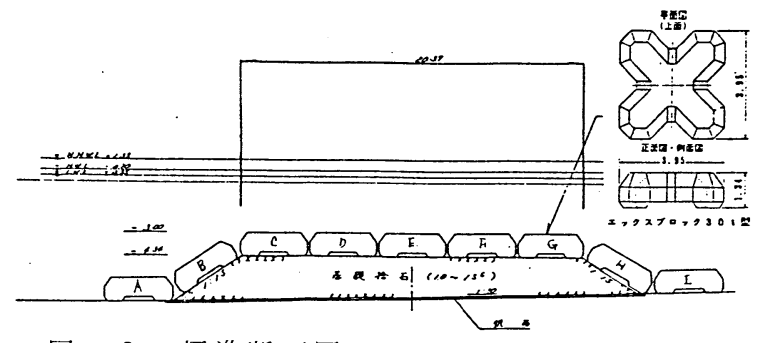

図 -2 標準断面図
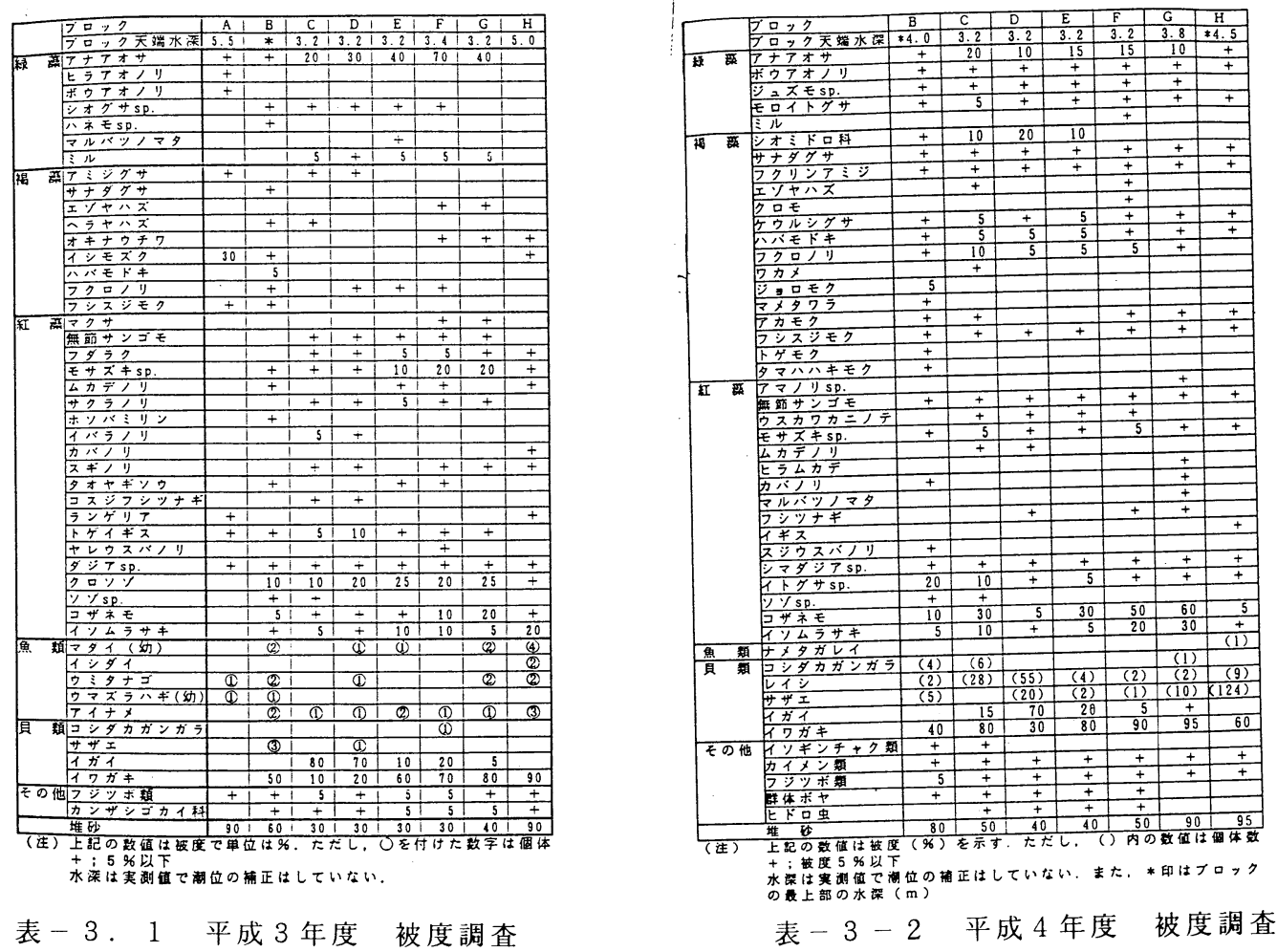
- 海草類

’93,94 亡も同種の 36 種類の海藻が確認された。主なものはアナアオサ、コザネモ、アオアサであ り、岸側になるほど被度が高く、波による影響と考えられる。ホンダワラ類がしだいに、入植し始めて いるため、アナアオサは少なくなると予想される。

- 貝類

’93,94 ともイガイ、イワガキが多く見られ、特に’94 年にはサザエの稚貝が蝟集していた。また、 イガイはアオアサとは異なり、沖側ほど被度が高い。一方、イワガキは岸側にいくほど、被度が高くな っていた。これは、波当たりの大きさに起因するものと考えられる。

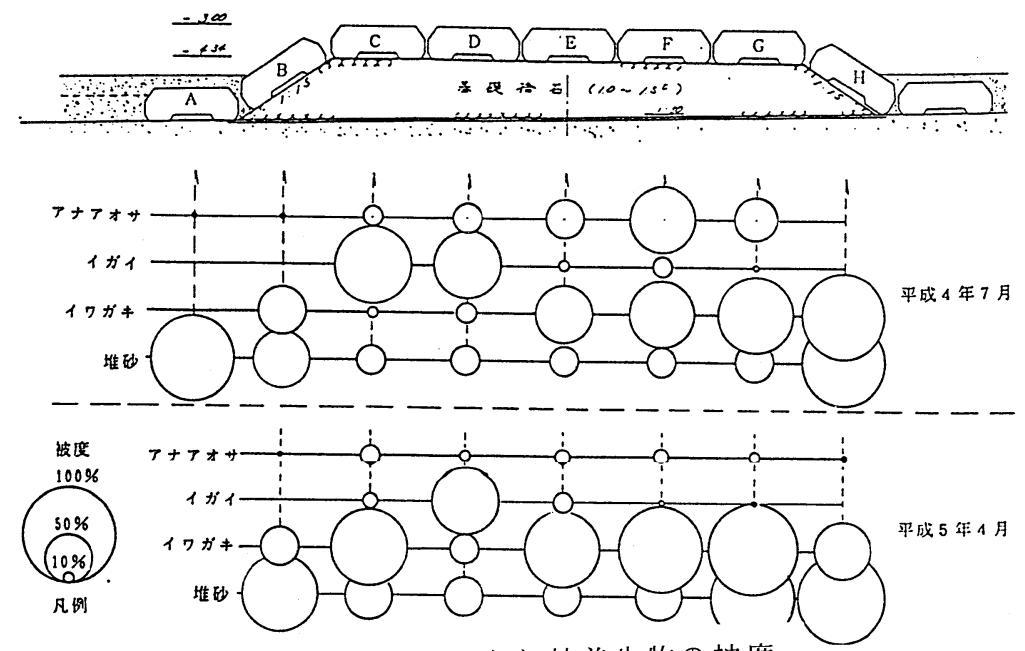

図 - 3 主な付着生物の被度

- 魚類

'93 にはマダイ (稚魚)、イシダイ、アイナメ等が多く観察できたが' 94 にはカレイのみであったが、

これは’94の調查時の海象条件が悪かったことによると推測される。

e. 考察

砂浜に施工された人エリーフにおいても、藻場としての効果と魚礁としての効果が期待できることが判 明した。

(2)人エリーフに関するヒヤリング調査

人エリーフ施工箇所において、人エリーフによる水産効果について漁業者（主に漁業協同組合）にヒヤリ ング調査を実施した。

調查対象地区は海象条件、人エリーフ被覆材の違う下記の 2 海岸とした。

・兵庫県三原郡西淡町慶野松原海岸

"津名郡五色町 "

瀬戸内海に位置し、潮位差が大きく、捨石が被覆材である。

・新潟県西頝城郡青海町市振海岸

日本海に位置し、潮位差が小さく、コンクリートブロックが被覆材である。

b. 調查方法

水産関係者への直接ヒヤリングを実施した。

c. 調查項目

' 94 年：人エリーフの問題点と期待、要望他

d. ヒヤリング結果

ヒヤリング調査の結果は両地域とも同じような点が指摘された。

・人エリーフには小魚が蝟集しており、また、藻場が造成されている。しかし、大型の魚はいないので、 直接、水揚げには影響しない。

・天端水深が浅く、船が上を通れないので、漁業利用には問題がある。また、人エリーフの位置がわか る標識が必要である。

・資源保護の役割を期待している。大型魚が住めるような魚礁と同時に設置してほしい。 


\section{e. 考察}

ヒヤリング調査の結果では生物潜水調查と同じ样に、藻場造成効果や稚魚の蝟集効果があることが判明 した。したがって、人エリーフは地域によらず、水産効果が期待でき、資源保護の役割を行うこともでき ると考えられる。

3.人工リーフ（水産協調型）水理機能性調查

水産協調型人エリーフの水理機能を調査するため、模型実験を実施した。

1) 水理実験

人エリーフの波高伝達率、水位上昇量、被覆材の重量算定法等の水理機能を把握するために被覆材を捨石及 コンクリートブロックにした場合の 2 次元水理模型実験を実施した。さらに、小段付きの人エリーフについて も波高伝達率の調查を行った。

実験諸元を表一 3 に示す。

a. 波高伝達率

人エリーフの波高伝達率の実験結果を図-4に示す。被覆材の種類による波高伝達率差異はみられない。 b. 水位上昇量

図－5に示すように、水位はリーフ上で急激に水位上昇が生じている。被覆材料ではブロックの法が水 位上昇量が少し大きいが、全体的な傾向は同じである。

c. 被覆材の安定

被覆材の安定は目視により観察した結果、法先から天端前部で被覆材が動く場合が多く、これは、天端 前部で砕波するためと推測される。

被覆材の安定重量人エリーフの法先勾配が小さいこと及び天端上の移動が比較的多いことから、ブレブ ナー・ドネリの算定式により求める。

d. 人エリーフ（水産協調型）水理機能性調査

人エリーフの断面に関する水理特性が把握された。また、従来の夕イプと小段を有した人エリーフの水 理特性はほぼ同じであった。

表 -3 実験諸元

\begin{tabular}{|c|c|c|}
\hline & 霓大 & 15 \\
\hline 生先水 $\mathrm{h}$ & 6. 0n. 4.0n & $20.0 \mathrm{cs} . \quad 13.3 \mathrm{cs}$ \\
\hline 天冰泟 & $2.0 \mathrm{~m}, \quad 1.0 \mathrm{~m} .0 .0 \mathrm{~m}$ & $6.7 \mathrm{cs} . \quad 3.3 \mathrm{cs} .0 .0$ \\
\hline 天啝 & 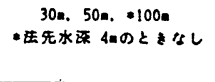 & 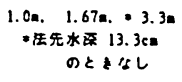 \\
\hline 蚂政 & $1 / 3$ & $1 / 3$ \\
\hline$x$ a & 1. 35 ton, $2.710 \mathrm{~s}, 5.4$ ton & 508. 1008. 2008 \\
\hline
\end{tabular}

21面故 $1 / 15$

\begin{tabular}{|c|c|c|}
\hline & 正䥼大 & 48 \\
\hline 生无水区 h & 6.0. & $20.0 \mathrm{ce}$ \\
\hline 天洒水 & 2.0 .0 .00 .0 .0$. & $6.7 \mathrm{cs}, \quad 3.3 \mathrm{~cm}, 0.0$ \\
\hline 天满田 & 30m. 50 & 1.0a. 1.67n \\
\hline 生勾区 & $1 / 3$ & $1 / 3$ \\
\hline 世石: & 1. 35100.2 .7600 .5 .4100 & 508. 1008.2008 \\
\hline
\end{tabular}

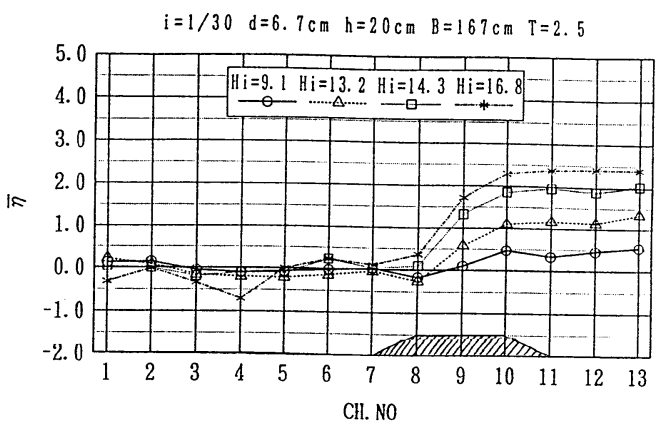

図-6 水位上昇量

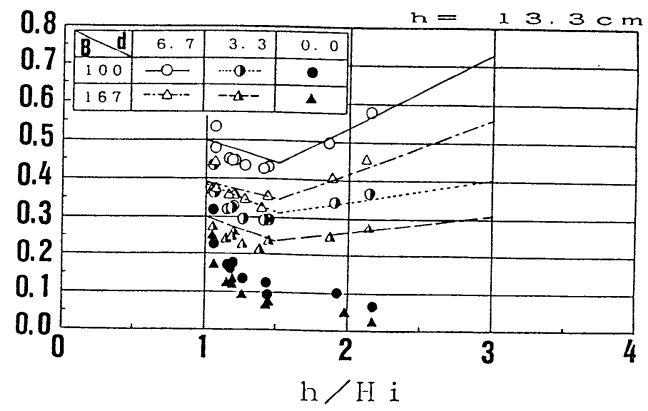

図-4 波高伝達率

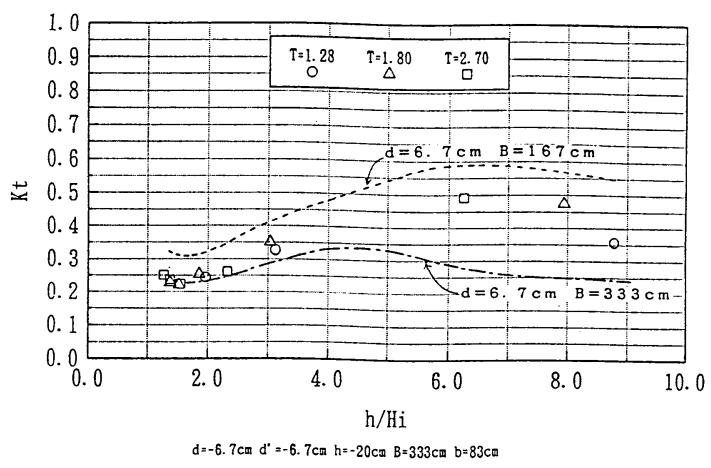

図-5 波高伝達率（小段付） 
4. 水産協調型人エリーフの断面形状の提案

人エリーフに必要とされる海岸保全機能は、前述の水理実験などから、必要な天端幅、天端高を決定する従来 の手法により求めることができる。

ここでは、人エリーフに加味すべき水産機能である「藻場としての機能」、「餌料としての寄り藻を滞留させ る機能」、「浮遊稚仔の着底を促進する機能」、「複雑で多様な空間を形成する機能」を考慮した断面形状を 4 タイプ提案する。また、表一 4 に特に良好な効果を期待できそうな対象魚種と基本形状を示す。

（A 型）

岸

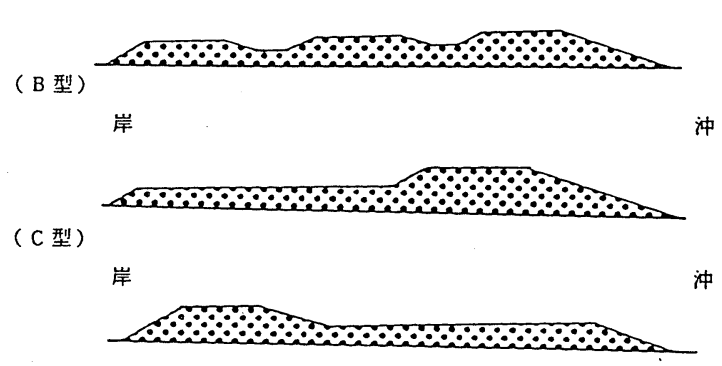

（D 型）

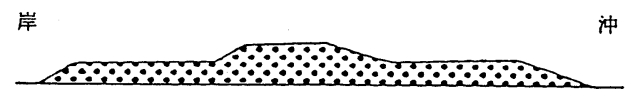

( $\mathrm{E}$ 型：従来型)

岸

a
表 - 4 対象漁種

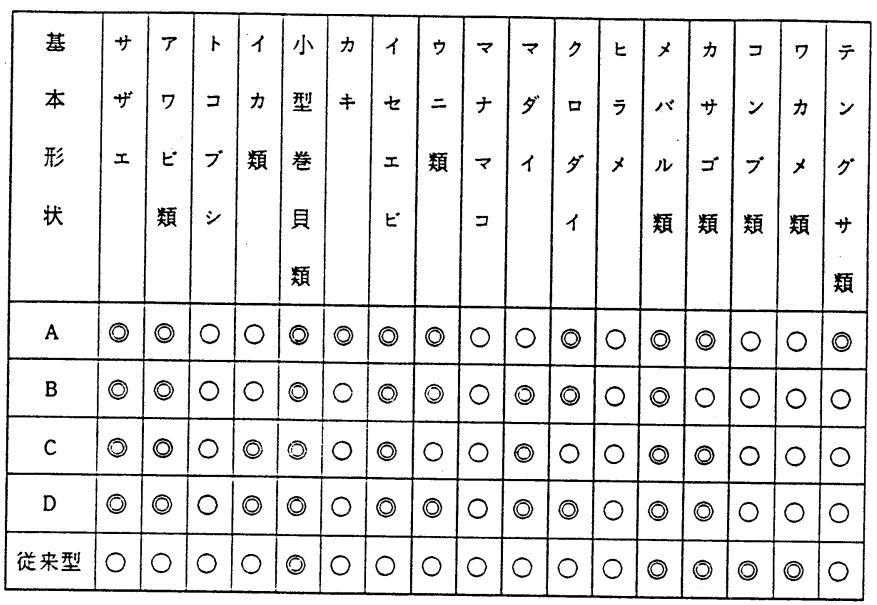

○：特に期待できる、○：期待できる

なお、当表はおおよその目女であり、地域や付近の海況や生息 生物の条件によって增殖効果は異なる。

図 -7 水産協調型基本形状図

5 . 水産協調型人エリーフの課題

人エリーフ（水産協調型）の課題を整理すると、以下になる。

・水産協調型の各断面に関する水理機能の詳細な検討。

水理機能については、すべての条件、範囲を網羅しているわけではなく、さらに詳細な検討が必要である。

・生物環境調查の継続

生物環境調查は 2 力年にわたり実施したが、今後、長期間にわたり生物の変遷を調查し、人工リーフの水 産効果を明確にする必要がある。また、条件の違う海域についても、水産効果の調査をすることが必要であ る。

6.おわりに

水産協調型人エリーフの断面形状について提案を行ったが、まだ、水理機能、水産効果については、不十分な 部分があり、今後、継続調査により、検討していく予定である。 